\title{
The Distribution and Origin of Carbonate Cements in Deep-Buried Sandstones in the Central Junggar Basin, Northwest China
}

\author{
Wang Furong, ${ }^{1}$ He Sheng, ${ }^{1}$ Hou Yuguang, ${ }^{1}$ Dong Tian, ${ }^{2}$ and He Zhiliang ${ }^{3}$ \\ ${ }^{1}$ Key Laboratory of Tectonics and Petroleum Resources, China University of Geosciences, Ministry of Education, Wuhan 430074, China \\ ${ }^{2}$ Department of Earth \& Atmospheric Sciences, University of Alberta, Edmonton, AB, Canada T6G 2E3 \\ ${ }^{3}$ SINOPEC Petroleum Exploration and Production Research Institute, Beijing 100083, China
}

Correspondence should be addressed to Hou Yuguang; sporthyg@126.com

Received 4 March 2017; Revised 19 May 2017; Accepted 4 June 2017; Published 14 September 2017

Academic Editor: Xiaorong Luo

Copyright (C) 2017 Wang Furong et al. This is an open access article distributed under the Creative Commons Attribution License, which permits unrestricted use, distribution, and reproduction in any medium, provided the original work is properly cited.

Extremely high porosities and permeabilities are commonly discovered in the sandstones of the Xishanyao Formation in the central Junggar Basin with the burial depth greater than $5500 \mathrm{~m}$, from which hydrocarbons are currently being produced. High content of carbonate cements (up to 20\%) is also observed in a similar depth range. Our study aimed to improve our understanding on the origin of carbonate cements in the Xishanyao Formation, in order to provide insights into the existence of high porosity sandstones at greater depths. Integrated analyses including petrographic analysis, isotopic analysis, fluid-inclusion, and core analysis were applied to investigate the distribution and origin of carbonate cements and the influence of high fluid pressure on reservoir quality. Textural evidences demonstrate that there are two generations of carbonate cements, precipitated at the temperature of $90^{\circ} \mathrm{C}$ and $120^{\circ} \mathrm{C}$, respectively. The carbonate cements with low $\delta^{13} \mathrm{C}_{\mathrm{PDB}}$ ranging from -19.07 to $-8.95 \%$ o dominantly occurred near the overpressure surface and especially accumulated at approximately $100 \mathrm{~m}$ below the surface. Our interpretation is that high content of carbonate cements is significantly influenced by early carbonate cements dissolution and migration under overpressure. Dissolution of plagioclase resulted in the development of internal pores and porosities of as much as $10 \%$ at $6500 \mathrm{~m}$ depth presumably.

\section{Introduction}

Carbonate cements in sandstones have variable mineralogy, texture, and chemical compositions and therefore exhibit significant effects on reservoir properties because it is commonly concentrated rather than being uniformly distributed. It is challenging to quantify the influence of concretionary carbonate cements on fluid flow in reservoirs because it is difficult to determine the distribution of diagenetic heterogeneity based on subsurface data. If the carbonate cements formed during early diagenetic stage, it could provide a framework that resists burial compaction and retains primary porosity until decarbonatization at greater burial depth [13]. Microlitic carbonate cements formed at early diagenetic stage can undertake partial overburden load that can slow compaction and can be dissolved into secondary pores under favorable geologic conditions. Extensive studies have been performed on carbonate cementation-dissolution reactions from the viewpoints of fluid-rock, organic-inorganic, and sandstone-mudstone interactions in the past 40 years by traditional geochemical methods, such as stable isotope and major and trace elements analysis [4-17] (Tan Jianxiong et al., 1999; dos Anjos et al., 2000; Hendry et al., 2000; Taylor et al., 2000; Fayek et al., 2001; Geoffrey Thyne, 2001; Ni Shijun et al., 2002; Wang Zhizhang et al., 2003; Xie Xinong et al., 2006; Wilkinson et al., 2006; Machent et al., 2007; Cao Jian et al., 2007).

It is observed that the favorable sandstone reservoirs are developed at the depth of $4500 \sim 6000 \mathrm{~m}$ in the central Junggar Basin. The average porosity is approximately $10 \%$ and the average permeability is $1 \times 10^{-3} \mu \mathrm{m}^{2}$. Although many studies have been carried out in this area, including petrographic analysis, formation-water geochemistry, fluid inclusions analysis, and overpressure characterization [13, 1823], there is still a lot of debate on the origins and types of 
porosity in this area. Some studies assumed that the primary residual pores are the dominant pore type and other studies assumed that secondary pores resulting from the dissolution of carbonate cements make more contributions to forming favorable reservoirs [24-26]. The negative correlation between porosity and the carbonate cements content indicates that the formation of secondary pores and carbonate cement dissolution probably have genetic relationships. It is unexpected that in sandstones high secondary porosity and high content of carbonate cements superimpose at the same depth. In this study, we attempt to investigate the origin of carbonate cements in deep-buried sandstones in the central Junggar Basin by applying a multidisciplinary approach, including petrographic, microthermometric, fluid-inclusion, and geochemical analysis. The main objectives of the study are as follows: (1) to quantify the chemical composition, size, and spatial distribution of carbonate cements and (2) to provide further insights into the effect of carbonates cements on petrophysical properties of deep-buried reservoirs.

\section{Geological Setting}

The Junggar Basin is one of the most prolific oil basin in China (Jiang and Fowler, 1986), covering an area of $136,000 \mathrm{~km}^{2}$. It is an intramontane basin bounded by multiple orogenic belts, including the Qinggelidi Mountains, the Kelameili Mountains, the Yilinheibiergen Mountains, the Bodega Mountains, and the Zhayier Mountains (Figure 1). The Junggar Basin is Late Palaeozoic-Cenozoic in age which is developed on the Junggar terrane, consisting of both Precambrian crystalline basement formed at $800 \mathrm{Ma}$ ago and slightly metamorphic Palaeozoic basement [28-33]. Our study area in this paper belongs to SINOPEC, located in the central depression of the hinterland of the basin which mainly consists of the west segment of the Changji Sag in the south (Figure 1).

The central depression area is one of the important areas for petroleum exploration. The characteristics of source rocks and reservoirs in the central Junggar Basin have been extensively studied. There were two sets of source rocks, including the Permian shales dominated by lacustrine-facies and the Jurassic mudstones dominated by swamp coalbearing. The deeply buried Jurassic sandstones dominated by fluvial-delta facies were main reservoirs with low porosity and permeability generally. However, relatively high porosity and permeability in sandstones display at some depth. At the same time, extensive development of overpressure is displayed over much of the central Junggar Basin. Much more hydrocarbon generated from Permian and Jurassic source rocks accumulated in the overpressured system (Wu Hengzhi et al., 2006; Li Pingping et al., 2006; Yang Zhi et al., 2007) (Figure 2).

Figure 3 shows the modelling burial history of Y1 well (Yongjin area) in Block 3 (see Figure 1 for its location). The erosion event generated an unconformity between Later Jurassic and Early Cretaceous. Therefore, the heat flow is the only variable that needs to be adjusted to match the presentday vitrinite reflectance data. Our modelling results indicated that the paleotemperature decreased gradually from the Permian to the present. This result is consistent with previous studies [34-37]. Drilling data demonstrated that the vitrinite reflectance $\left(R_{o}\right)$ ranges within $0.65 \sim 0.82 \%$ in the Middle Jurassic Xishanyao Formation. To match the measured and the predicated vitrinite reflectance data, BasinMod simulation software aims to rebuild the geothermal history. At present, the temperature of Jurassic strata was approximately between $120^{\circ} \mathrm{C}$ and $150^{\circ} \mathrm{C}$, giving a gradient of $2.2^{\circ} \mathrm{C} / 100 \mathrm{~m}$. With the results of homogenization temperature, the main oil pools in the third central block formed from the end of the early Cretaceous to the early stage of Paleogene (from $75 \mathrm{Ma}$ to $60 \mathrm{Ma}$ ) [38]. At the same time, the crude oil was detected in high levels of 25-norhopane from Y1 well, which explained that an early stage of hydrocarbon charging occurred in the late Jurassic [38].

\section{Samples and Methods}

125 core samples were obtained from six wells (Y1, Y2, Y3, Y6, Y7, and Y8) at a depth range of 5500-6200 $\mathrm{m}$ from Jurassic Xishanyao Formation (Figure 1). The strategy of sample collection is based on the characteristics of lithology. Generally, an interval of one meter is between the two samples, if the cores have homogeneous qualities. The ternary plot indicates that the Xishanyao Formation sandstones are dominantly litharenite and feldspathic litharenite as they have an average framework composition of $\mathrm{Q}_{28} \mathrm{~F}_{13} \mathrm{~L}_{59}$ (Figure 4).

Carbonate cements were investigated by using epoxyimpregnated thin sections, cathodoluminescence, and SEM/EDX images. Conventional core samples and epoxyimpregnated thin sections analysis was conducted on the MIAS 2000 microscopes by the Experimental Research Center of Wuxi Research Institute of Petroleum Geology of SINOPEC and Research Center of Shengli Oilfield Institute of Geology of SINOPEC. Analysis was performed at the room temperature of $25^{\circ} \mathrm{C}$ and the relative humidity of $60 \%$.

Cathodoluminescence analysis was conducted on the CL8200 MK5 cathodoluminescence microscopy by the Experimental Research Center of Wuxi Research Institute of Petroleum Geology of SINOPEC. Analysis was performed at the room temperature of $27^{\circ} \mathrm{C}$ and the relative humidity of $40 \%$.

SEM/EDX analysis was performed on the sem-xl30 and EDX-INCA scanner by the Experimental Research Center of Wuxi Research Institute of Petroleum Geology of SINOPEC. Analysis was performed at the room temperature of $22^{\circ} \mathrm{C}$ and the relative humidity of $60 \%$.

Carbon and oxygen isotope analysis was carried out on the MAT253 Gas isotope mass spectrometer made in Germany Firmigan company. Analysis was performed at the sample tray temperature of $72^{\circ} \mathrm{C}$, chromatography temperature of $40^{\circ} \mathrm{C}$, and helium gas pressure of $100 \mathrm{KPa}$.

Electron microprobe analysis was conducted on the JXA8100 electron probe microanalyser at the State Key Laboratory of Geological Processes and Mineral Resource. Analysis was performed at the room temperature of $23^{\circ} \mathrm{C}$ and the relative humidity of $65 \%$.

\section{Results}

4.1. Thin Section Analysis. Thin section images demonstrate that the dominant cements are carbonates, which consists 


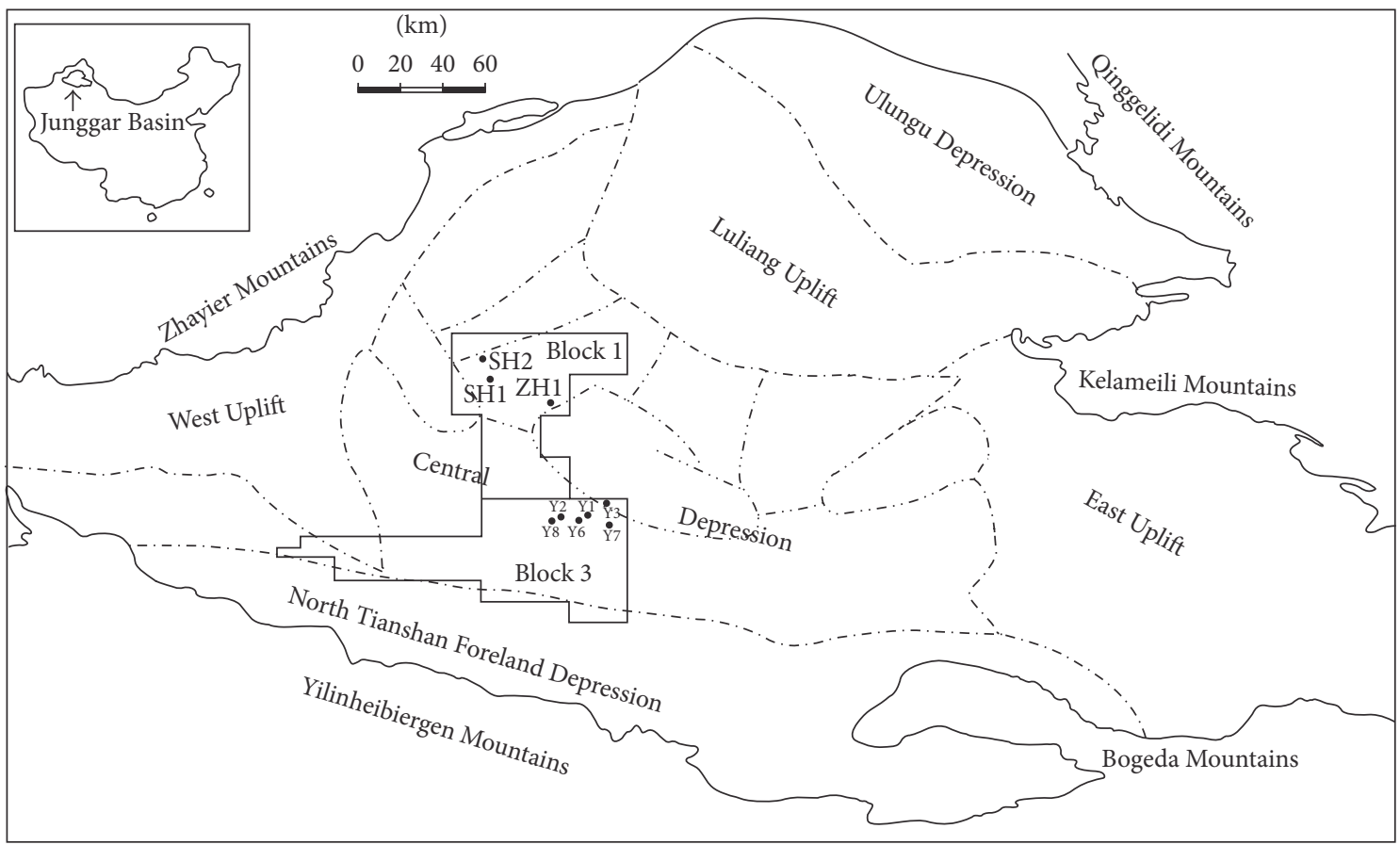

FIGURE 1: Map showing the tectonic units and studied well locations in the central Junggar Basin.

of a high volume of ferroan calcite and ankerite. At the same time, a small amount of dolomite developed in some wells. Thin section images show that both ferroan and nonferroan calcites commonly occurred as extensive, singlecrystal poikilotopes that filled with the intergranular pores (Figure 5(a)). In contrast, ankerite cements are regular to rhombic, replacing calcites with an undulating extinction characteristic (Figures 5(b) and 5(c)). Dolomite cements were also observed in the form of replacing calcites (Figure $5(\mathrm{~d})$ ). Some calcite crystal filled in intergranular pores and postdated quartz overgrowth (Figures 5(e) and 5(f)). Some thin section images show that carbonate cements replaced detrital quartz, feldspar, or rock fragments. The abundance of carbonate can be up to $20 \%$ and generally in the range of $1-10 \%$ within the six studied wells (Figure 6). At the same time, particle contact modes were different because of maldistributed distribution. Some particles were in point contact where carbonate cements develop, while others were in straight of concavoconvex contact. Moreover, carbonates with different mineral compositions distributed in different wells, such as ankerite cements, generally distributed in wells Y2, Y6, and Y8 with an average concentration of $4.5 \%$ and calcite cements generally distributed in wells Y1, Y3, and Y7 with an average content of $4.1 \%$.

4.2. Cathodoluminescence. Under the cathodoluminescent (CL) images, the relative content of manganese $(\mathrm{Mn})$ and iron (Fe) in carbonate cements can be used to provide insights into the redox conditions when the pore fluid formed. $\mathrm{Mn}$ in calcites is an activator in CL, while Fe acts as a quencher. Carbonate cements with $\mathrm{Mn}>\mathrm{Fe}$ show bright luminescence, whereas calcite cements with $\mathrm{Fe}>\mathrm{Mn}$ exhibit dull- luminesce. In Block 3, the carbonate cements partially show bright luminesce (Figure $5(\mathrm{~g})$ ) and others show shade of bright luminesce (Figure 5(h)). Cathodoluminescence of these calcite cements can be interpreted by their origin in sandstones.

4.3. EDX Analysis. The trace element data of 14 core samples, determined by EDX analysis, are presented in Table 1. Carbonate cements are generally rich in Fe with low concent of $\mathrm{Mn}$ and $\mathrm{Mg}$, and the concentration of $\mathrm{Ca}$ increases with increasing burial depth.

4.4. Stable Isotopes. $\delta^{13} \mathrm{C}$ and $\delta^{18} \mathrm{O}$ of the carbonate cements, together with burial and thermal histories, can be used to reveal the origin of the cements. Stable isotopes data in Yongjin area are presented in Table 2. Carbon isotope values range from -19.07 to $-5.87 \%$ ( $\mathrm{PDB}$ ) with average value of $-8.95 \%$ ( $\mathrm{PDB})$. The oxygen isotope values range from -21.08 to $-13.96 \%$ o $(\mathrm{PDB})$ with average value of $-17.5 \%$ o $(\mathrm{PDB})$. The $\delta^{13} \mathrm{C}$ and $\delta^{18} \mathrm{O}$ values increase with increasing burial depth and there is a positive correlation between the $\delta^{13} \mathrm{C}$ and $\delta^{18} \mathrm{O}$ values.

\section{Discussion}

5.1. Origins of Carbonate Cements and Source of Fluid. Petrographic observations revealed at least two generations of carbonate cements. The first-generation carbonate occurred as blocky crystalline calcite, which filled within the intergranular pores reduced considerably by mechanical and chemical compaction. This kind of cements occurred in the form of coating quartz grains, preventing authigenic quartz from overgrowing (Alaa et al., 2007). And they dominated in the deeply buried sandstones and filled with iron $(\mathrm{Fe})$ content, 


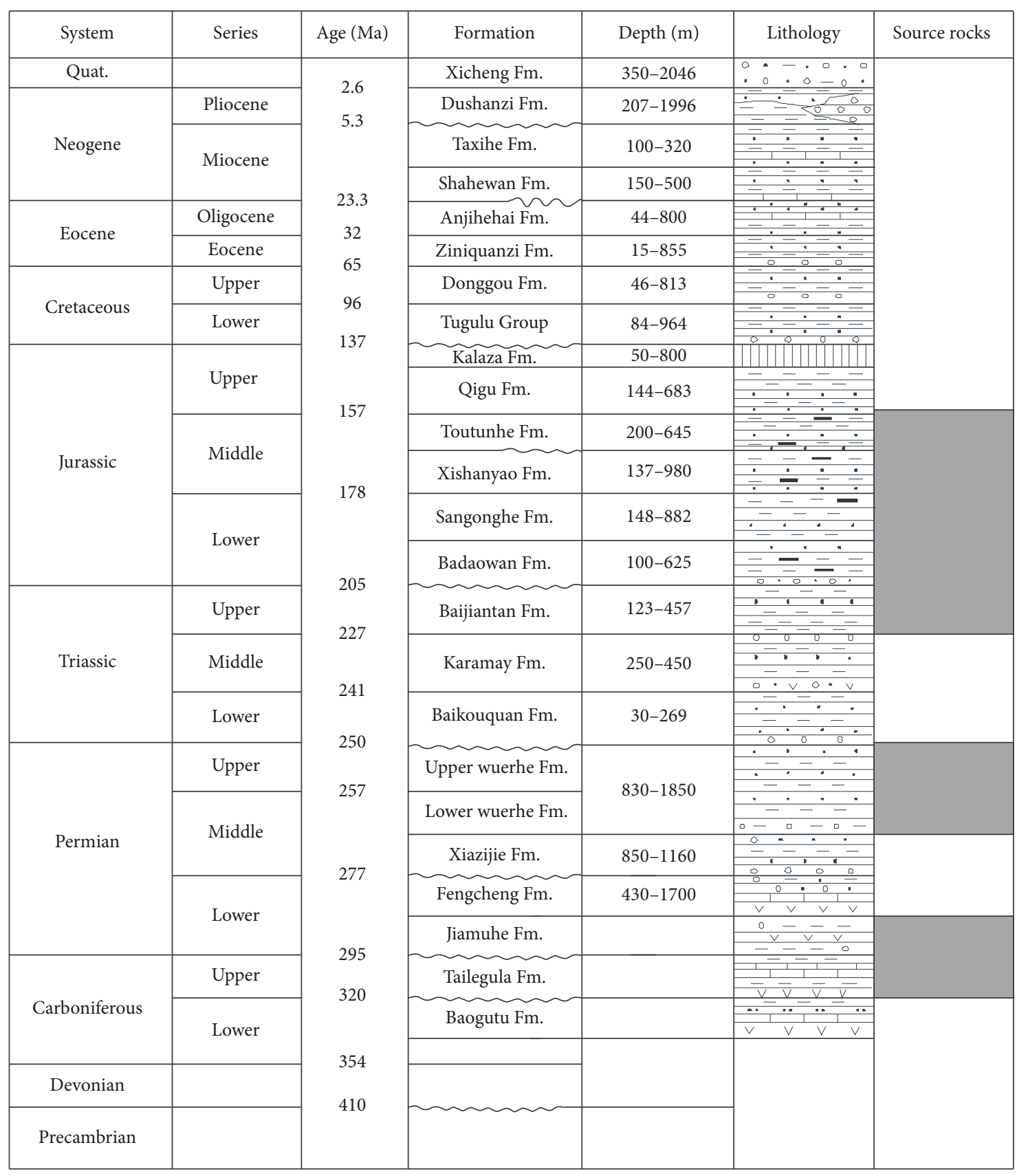

\begin{tabular}{ll}
\hline$\ldots$ & Siltstone \\
$E=$ Mudstone \\
$\ldots$ Coarse sandstone \\
$\ldots$ Coal
\end{tabular}

Conglomerate
Limestone
Volcanic
Erode

FIGURE 2: Stratigraphic column and correlation of stratum in the center of Junggar Basin (2002).

which belonged to late diagenesis cements. The secondgeneration carbonate cement was ankerite, which replaced calcite (Figure 5(c)).

$\delta^{13} \mathrm{C}$ and $\delta^{18} \mathrm{O}$ in the carbonate cements can be used to unravel the origins of the cements. The main mechanisms of generation of $\delta^{13} \mathrm{C}$-depleted $\mathrm{CO}_{2}$ in large amounts during burial are discussed by Irwin et al. [39], including diagenetic carbonate in area I, carbonate relating to biogas in area II, and carbonate relating to organic acid in area III (Jansa et al., 1990; Wang Darui, 2000; Wilkinson et al., 2006) (Figure 7). 29 samples from Xishanyao Formation (J2x) and 11 samples from Toutunhe formation (J2t) were collected between $5500 \mathrm{~m}$ and $6200 \mathrm{~m}$ for the carbon and oxygen stable isotopic analysis. The results were shown in Figure 7 as 


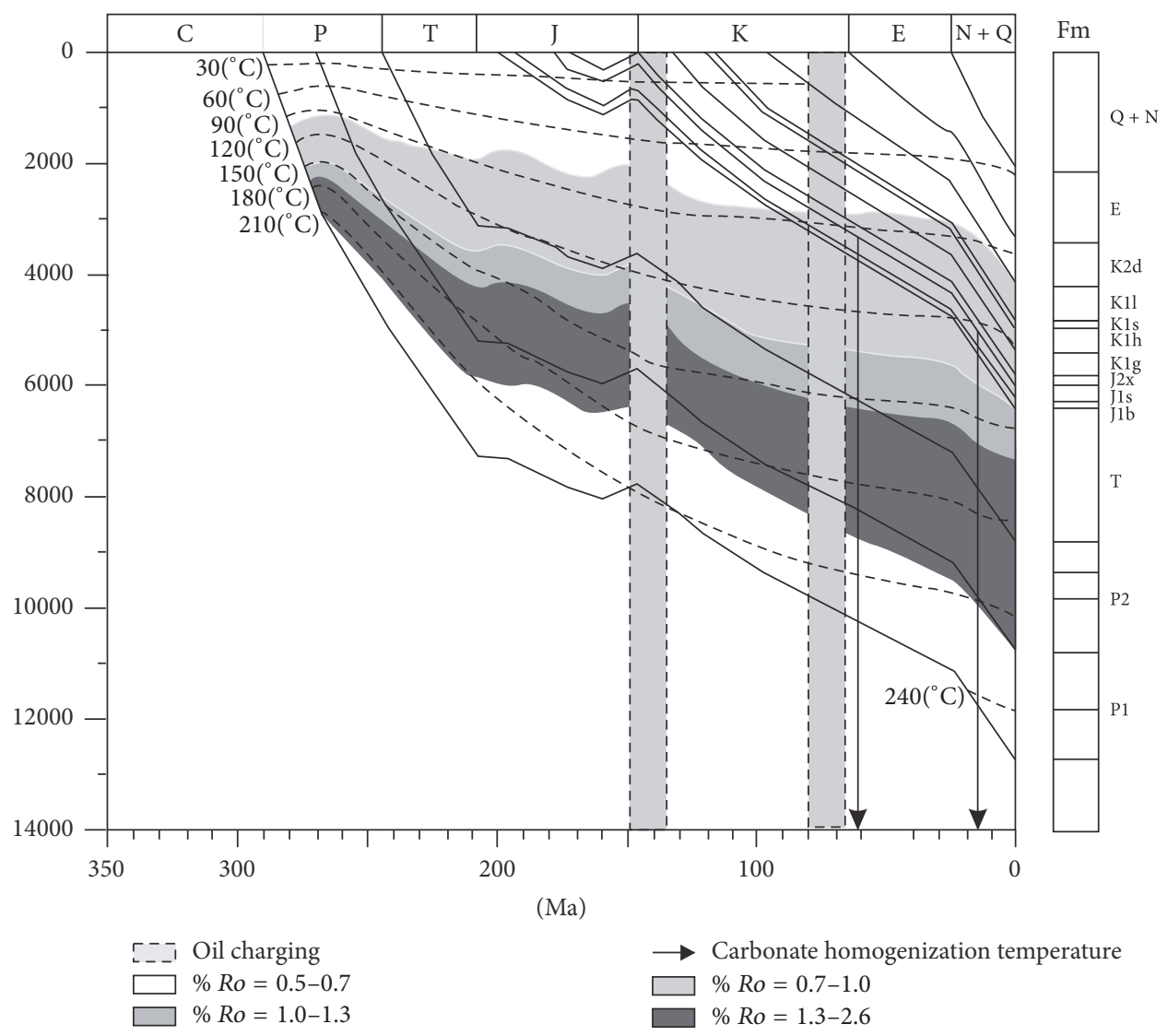

Figure 3: Generalized burial and thermal histories of Y1 well from Block 3 in the central Junggar Basin. Location of the example well is marked in Figure 1.

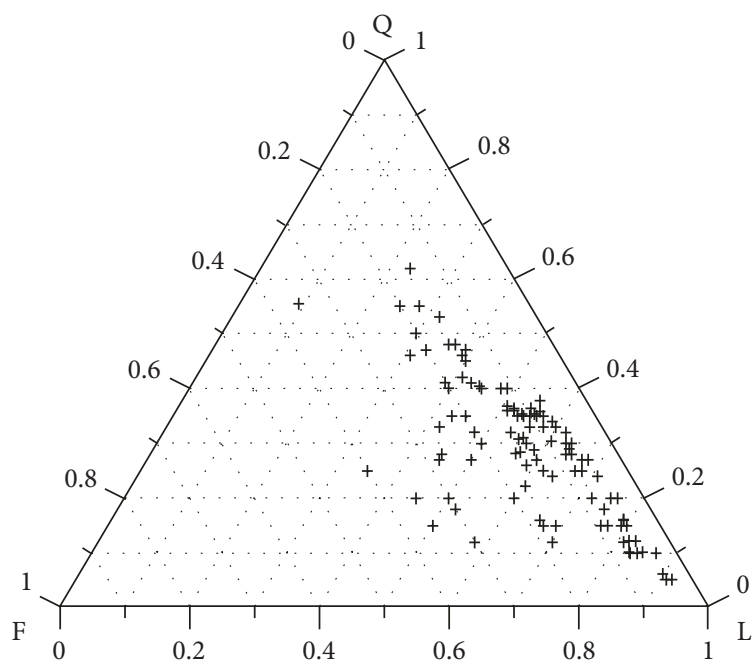

FIGURE 4: Ternary plot showing sandstone compositions according to Folk's (1980) classification scheme.

a plot of $\delta^{18} \mathrm{O}(\mathrm{PDB})$ versus $\delta^{13} \mathrm{C}(\mathrm{PDB})$ that more negative $\delta^{13} \mathrm{C}$ values are generally accompanied by more negative $\delta^{18} \mathrm{O}$ values indicating that the carbonate cements were significantly influenced by organic matter alteration during burial (Figure 7) in area III. Rare input of $\delta^{12} \mathrm{C}$ with increasing burial and temperature from thermal alteration of organic matter is indicated by the strong correlation between $\delta^{13} \mathrm{C}$ and $\delta^{18} \mathrm{O}$ [39-41].

With limited fluid-inclusion data of carbonate cements and quartz overgrowth, the precipitation was formed at about $100^{\circ} \mathrm{C}$ and $80-130^{\circ} \mathrm{C}$, respectively (Table 3 ). From Figures $5(\mathrm{e})$ and 5(f), the phenomena that carbonate crystal postdates quartz overgrowth revealed that at least part of carbonate cement deposited at $120^{\circ} \mathrm{C}$ (inclusion homogenization temperature of overgrowth concentrating in $120^{\circ} \mathrm{C}$ ). From Figure 3 , the carbonate formation mainly resulted from the later hydrocarbon charging.

5.2. Effect on Reservoir Properties. Reservoir physical properties data indicate that porosity near the overpressure surface is relatively high, mainly concentrating in the depth range $+50 \mathrm{~m} \sim-250 \mathrm{~m}$ of the overpressure top surface, and the carbonate cements are concentrated in these high porosity zone (Figure 8). Thin section images and microscope analysis were used to investigate the origin that why do the high porosity and carbonate cements superimpose in depth, when the formation water flowed and broke through the overpressure surface, causing the precipitation and concentration of calcite near the overpressure surface because of the unstable temperature and pressure [42, 43] (Yang Zhi, 2011). 


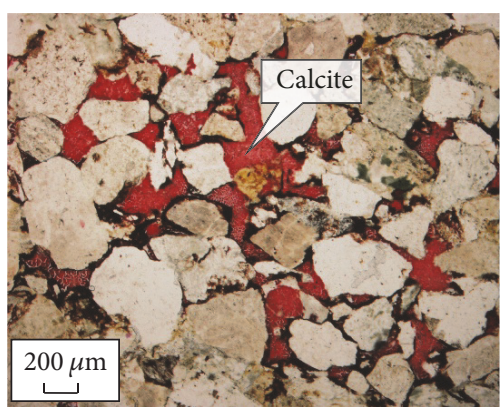

(a)

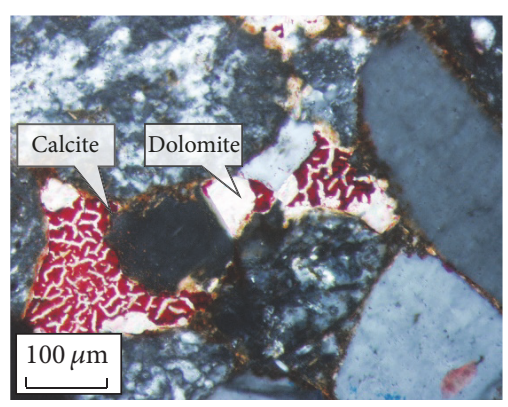

(d)

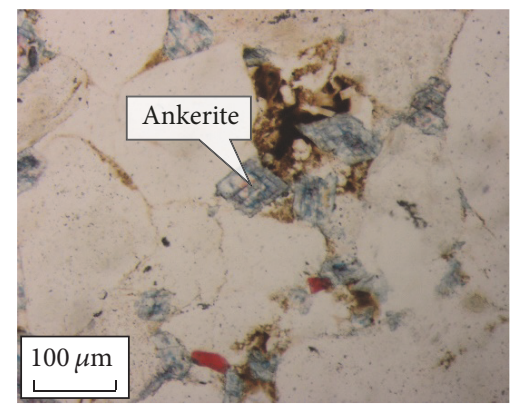

(b)

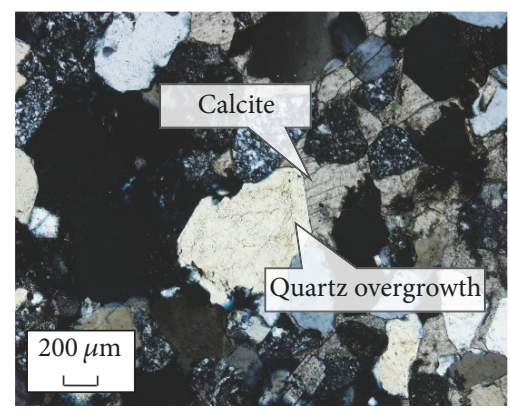

(e)

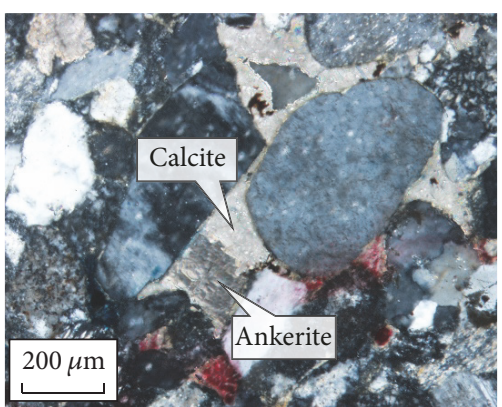

(c)

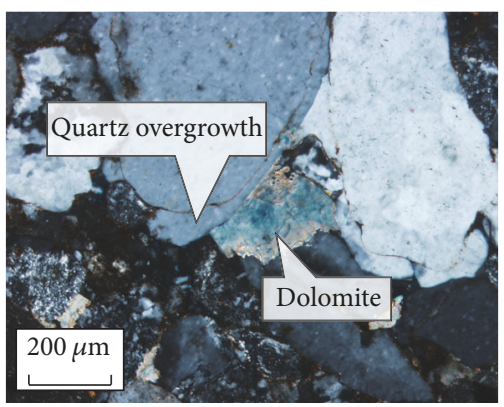

(f)

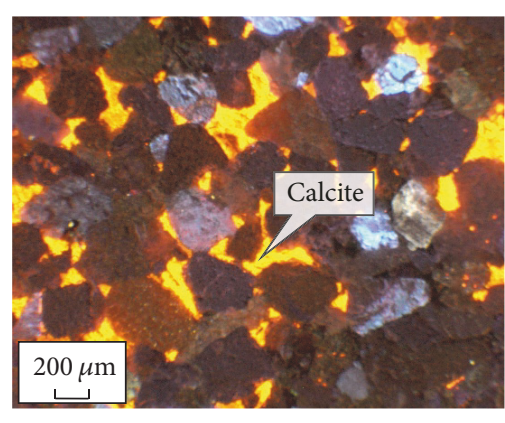

(g)

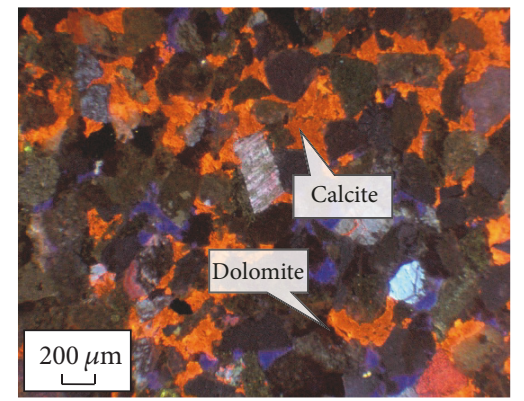

(h)

Figure 5: Photomicrographs showing petrographic features of the Xishanyao Formation sandstones. Most common types of mineralogy variations in sandstone cement, including (a) secondary pores were mainly filled by crystal calcite, major pores were filled by asphalt at the edges, and the photomicrograph is a stained red-epoxy-impregnated thin sections of conventional core samples by plane-polarized light with magnification of 40 (Y6 well at 6,048.59 m); (b) single-crystal rhombus ankerite, the photomicrograph is a stained blue-epoxy-impregnated thin sections of conventional core samples by plane-polarized light with magnification of 200 (Y6 well at $6028.52 \mathrm{~m}$ ); (c) a few ankerites replace calcites in a red-epoxy-impregnated thin sections of conventional core samples with cross-polarized light with magnification of 100 (Y2 well at $5966.02 \mathrm{~m}$ ); and (d) a few dolomites replace calcites in a stained red-epoxy-impregnated thin sections of conventional core samples with cross0polarized light with magnification of 200 (Y2 well at $5967.02 \mathrm{~m}$ ); (e) crystal calcite filled in pores, and crystal postdate quartz overgrowth in a stained blue-epoxy-impregnated thin sections of conventional core samples by cross-polarized light with magnification of 40 (Y1 well at $5876 \mathrm{~m}$ ); (f) dolomites develop in a stained blue-epoxy-impregnated thin sections of conventional core samples by planepolarized light with magnification of 100 (Y2 well at $6000.25 \mathrm{~m}$ ); (g) calcite cements show bright yellow luminescence in cathodoluminescence photomicrograph with magnification of 40 (Y7 well at $6095 \mathrm{~m}$ ); (h) calcite cements show saffron luminescence and dolomites cements are disphotic in cathodoluminescence photomicrograph with magnification of 40 (Y8 well at $6099.46 \mathrm{~m}$ ).

Observation from thin section images indicate that secondary intergranular pores are the dominant pore type (Figure 9). In contrast to the characteristics of minerals by planepolarized and cross-polarized light, the remnant of calcite can be found after dissolution developing in the surrounding pores. Data from electron microprobe analysis indicate that the secondary intergranular pores resulted from dissolving intergranular carbonate cements and feldspar (Figure 10, Table 4), mainly generated by calcite dissolution. Megapores were mostly formed by the dissolution of albite and less by $\mathrm{K}$-feldspar and kaolinite in situ deposit which shows that pore configuration has good connection. These evidences demonstrate that the large-scale dissolution of intergranular carbonate cements can generate more intergranular pores and make the pore more connected.

Although sandstones experienced extensive mechanical compaction and chemical compaction, the point or straight grain contact and the pervasive development of intergranular 
TABLE 1: Composition from EDX analysis of carbonate cements in sandstone of Block 3.

\begin{tabular}{|c|c|c|c|c|c|c|c|c|c|}
\hline \multirow{2}{*}{ Well } & \multirow{2}{*}{ Depth/m } & \multicolumn{8}{|c|}{ Content/\% } \\
\hline & & $\mathrm{Na}_{2} \mathrm{O}$ & $\mathrm{MgO}$ & $\mathrm{Al}_{2} \mathrm{O}_{3}$ & $\mathrm{SiO}_{2}$ & $\mathrm{CaO}$ & $\mathrm{MnO}$ & $\mathrm{Fe}_{2} \mathrm{O}_{3}$ & $\mathrm{~K}_{2} \mathrm{O}$ \\
\hline $\mathrm{Y} 1$ & 6117.38 & & & 2.22 & 5.54 & 82.59 & 4.31 & 5.35 & \\
\hline \multirow{2}{*}{ Y2 } & 5970.53 & & 17.48 & & 5.55 & 47.38 & 4.43 & 25.16 & \\
\hline & 6001.23 & & 19.00 & & 6.79 & 63.28 & 6.41 & 4.52 & \\
\hline \multirow{2}{*}{ Y3 } & 5614.22 & 1.37 & 13.92 & 3.33 & 8.70 & 43.33 & 3.47 & 24.45 & \\
\hline & 5868.00 & & 1.59 & 3.04 & 4.78 & 79.22 & 5.95 & 5.04 & 0.37 \\
\hline \multirow{2}{*}{ Y6 } & 6028.60 & & 21.22 & & & 52.30 & 3.63 & 22.85 & \\
\hline & 6084.00 & & & 1.36 & 5.26 & 91.04 & & 2.34 & \\
\hline \multirow{2}{*}{ Y7 } & 6095.00 & & & 1.27 & 2.45 & 92.39 & 1.76 & 2.13 & \\
\hline & 6101.55 & & 3.84 & 4.56 & 15.13 & 45.61 & 7.50 & 22.51 & 0.84 \\
\hline \multirow{2}{*}{ Y8 } & 6088.55 & & 21.43 & 2.44 & 1.99 & 51.05 & & 23.08 & \\
\hline & 6096.20 & & & 0.95 & 9.21 & 85.44 & & 4.02 & 0.38 \\
\hline
\end{tabular}

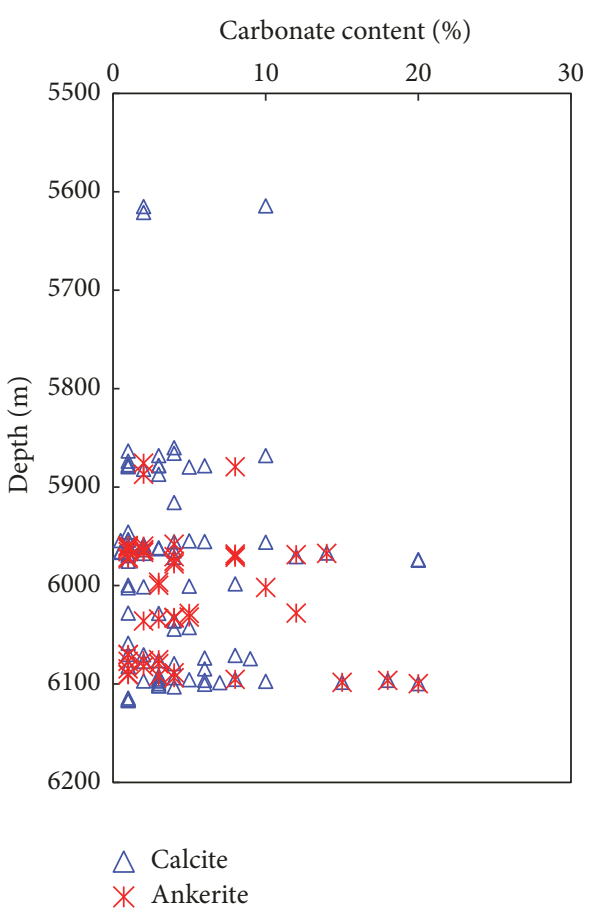

FIGURE 6: Regional abundance of carbonate cements versus depth in the Jurassic Formation. Text data from 125 core samples show that carbonate is abundant from below $5800 \mathrm{~m}$ and increases with depth down to about $6100 \mathrm{~m}$ burial depth. The contents of calcite have little changes with the depth. However, ankerite has a sharp interface of $5850 \mathrm{~m}$ burial depth and the content increases with the depth.

pores suggest that the formation of carbonate cements predated intensive physical compaction. Firstly, early carbonate cements occupied the intergranular pore space which increased rock mechanical strength and resisting ability to compaction. Therefore, the sandstone reservoir can develop high primary porosity even in deeply buried conditions. Secondly, early carbonate cements provided materials for dissolution which can form a large amount of secondary intergranular porosity and feldspar dissolution further improved
TABLE 2: Carbon and oxygen isotope values in Xishanyao formation sandstones of Block 3 .

\begin{tabular}{|c|c|c|c|c|}
\hline Well & Depth/m & $\delta^{13} \mathrm{C}_{\mathrm{PDB}} / \%$ & $\delta^{18} \mathrm{O}_{\mathrm{PDB}} / \% 0$ & $\begin{array}{c}\text { Isotopic } \\
\text { temperature } /{ }^{\circ} \mathrm{C}\end{array}$ \\
\hline $\mathrm{Y} 1$ & 5880.00 & -8.21 & -19.05 & 128.92 \\
\hline \multirow{7}{*}{ Y7 } & 6095.00 & -7.55 & -18.53 & 124.17 \\
\hline & 6095.50 & -7.37 & -16.44 & 106.21 \\
\hline & 6096.80 & -8.18 & -19.95 & 137.06 \\
\hline & 6098.60 & -7.52 & -17.87 & 118.36 \\
\hline & 6099.59 & -7.60 & -17.53 & 115.42 \\
\hline & 6101.80 & -7.49 & -16.15 & 103.82 \\
\hline & 6103.60 & -7.65 & -18.17 & 120.99 \\
\hline \multirow{7}{*}{ Y8 } & 6088.50 & -11.63 & -16.68 & 108.21 \\
\hline & 6088.80 & -12.38 & -16.88 & 109.89 \\
\hline & 6092.00 & -10.82 & -17.65 & 116.46 \\
\hline & 6093.30 & -11.08 & -16.04 & 102.92 \\
\hline & 6093.50 & -10.72 & -17.86 & 118.28 \\
\hline & 6094.30 & -10.80 & -16.78 & 109.05 \\
\hline & 6099.50 & -7.34 & -17.40 & 114.31 \\
\hline \multirow{6}{*}{ Y3 } & 5614.90 & -7.05 & -17.36 & 113.97 \\
\hline & 5620.80 & -7.10 & -18.17 & 120.99 \\
\hline & 5621.10 & -7.61 & -18.43 & 123.28 \\
\hline & 5865.60 & -5.87 & -21.08 & 147.73 \\
\hline & 5866.35 & -19.07 & -14.68 & 92.04 \\
\hline & 5867.90 & -5.92 & -21.28 & 149.65 \\
\hline \multirow{6}{*}{ Y6 } & 5977.00 & -8.31 & -13.96 & 86.5 \\
\hline & 6034.90 & -6.52 & -17.72 & 117.06 \\
\hline & 6044.80 & -6.95 & -19.03 & 128.64 \\
\hline & 6076.50 & -7.08 & -16.29 & 104.97 \\
\hline & 6084.60 & -7.04 & -19.20 & 130.18 \\
\hline & 6098.50 & -9.70 & -18.35 & 122.57 \\
\hline \multirow{2}{*}{$\mathrm{Y} 2$} & 5961.50 & -6.36 & -15.06 & 95.03 \\
\hline & 6004.30 & -9.97 & -17.87 & 118.36 \\
\hline
\end{tabular}

Isotopic temperature $\left({ }^{\circ} \mathrm{C}\right)=16.45-4.31(\delta c-\delta w)+0.14(\delta c-\delta w)^{2}$, according to Epstein et al. [27]. 
TABLE 3: Fluid-inclusion data from quartz overgrowth and carbonate cements.

\begin{tabular}{|c|c|c|c|c|}
\hline Well & Depth, m & Numbers of inclusion & $\begin{array}{c}\text { Carbonate homogenization } \\
\text { temperature, }{ }^{\circ} \mathrm{C} \\
\end{array}$ & $\begin{array}{c}\text { Quartz overgrowth } \\
\text { homogenization temperature, }{ }^{\circ} \mathrm{C}\end{array}$ \\
\hline \multirow{4}{*}{ Y1 } & 5828.2 & 1 & 100 & \multirow{4}{*}{$115,120,125,127$} \\
\hline & 5876.38 & 4 & & \\
\hline & 6114.7 & 1 & 98 & \\
\hline & 6116.87 & 2 & 92,98 & \\
\hline \multirow{3}{*}{$\mathrm{Y} 2$} & 5953.66 & 6 & 96 & $85,88,116,120,132$ \\
\hline & 5970.53 & 3 & & \multirow[t]{2}{*}{$102,117,127$} \\
\hline & 6002.15 & 2 & 98,102 & \\
\hline \multirow{2}{*}{ Y6 } & 6027.44 & 2 & 96,102 & \multirow[b]{2}{*}{80,134} \\
\hline & 6028.6 & 2 & & \\
\hline
\end{tabular}

TABLE 4: Electron microprobe analysis of residual mineral contents in secondary pores of wells in studied area.

\begin{tabular}{ccccccccccccc}
\hline \multirow{2}{*}{ Well } & Position & & \multicolumn{7}{c}{ Content/\% } \\
& & $\mathrm{SiO}_{2}$ & $\mathrm{TiO}_{2}$ & $\mathrm{Al}_{2} \mathrm{O}_{3}$ & $\mathrm{FeO}$ & $\mathrm{MnO}$ & $\mathrm{MgO}$ & $\mathrm{CaO}$ & $\mathrm{Na}_{2} \mathrm{O}$ & $\mathrm{K}_{2} \mathrm{O}$ & $\mathrm{Cr}_{2} \mathrm{O}_{3}$ & $\mathrm{Total}^{2}$ \\
\hline \multirow{2}{*}{$\mathrm{SH} 1$} & $\mathrm{a}$ & 63.55 & 0.00 & 17.89 & 0.00 & 0.00 & 0.00 & 0.00 & 1.00 & 16.10 & 0.00 & 98.54 \\
& $\mathrm{~b}$ & 0.16 & 0.00 & 0.03 & 0.03 & 0.00 & 0.40 & 53.50 & 0.00 & 0.00 & 0.00 & 54.12 \\
\hline \multirow{2}{*}{$\mathrm{ZH} 1$} & $\mathrm{c}$ & 68.13 & 0.00 & 19.57 & 0.05 & 0.00 & 0.00 & 0.00 & 12.03 & 0.02 & 0.00 & 99.80 \\
& $\mathrm{~d}$ & 64.13 & 0.03 & 18.02 & 0.05 & 0.00 & 0.00 & 0.00 & 0.31 & 16.65 & 0.00 & 99.19 \\
\hline \multirow{2}{*}{$\mathrm{SH} 2$} & $\mathrm{e}$ & 51.02 & 0.00 & 18.75 & 0.05 & 0.00 & 0.00 & 0.31 & 8.17 & 0.00 & 0.00 & 78.30 \\
& $\mathrm{f}$ & 0.00 & 0.00 & 0.00 & 0.59 & 0.62 & 0.44 & 60.92 & 0.00 & 0.00 & 0.00 & 62.57 \\
& $\mathrm{~g}$ & 0.08 & 0.00 & 0.00 & 58.11 & 0.00 & 0.00 & 0.00 & 0.00 & 0.00 & 0.00 & 58.19 \\
\hline & $\mathrm{h}$ & 0.81 & 0.00 & 0.13 & 1.49 & 1.34 & 0.17 & 52.45 & 0.00 & 0.00 & 0.02 & 56.41 \\
$\mathrm{Y} 1$ & $\mathrm{i}$ & 64.73 & 0.00 & 18.32 & 0.00 & 0.00 & 0.00 & 0.00 & 0.30 & 16.69 & 0.00 & 100.04 \\
& $\mathrm{j}$ & 70.41 & 0.00 & 20.46 & 0.10 & 0.00 & 0.00 & 0.16 & 10.48 & 0.00 & 0.00 & 101.61 \\
\hline
\end{tabular}

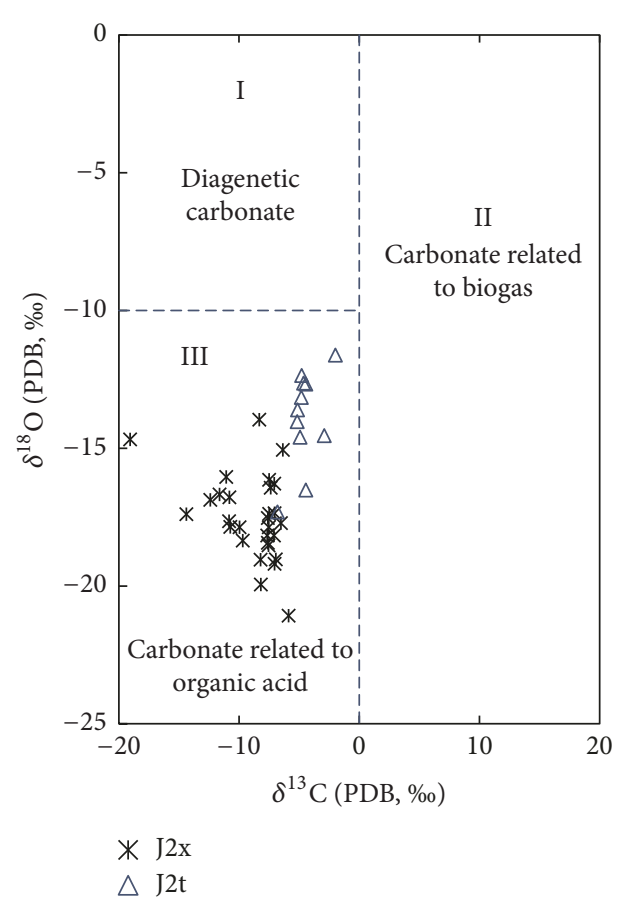

FIGURE 7: Stable isotopic data of carbon and oxygen for carbonate cements of Block 3 .

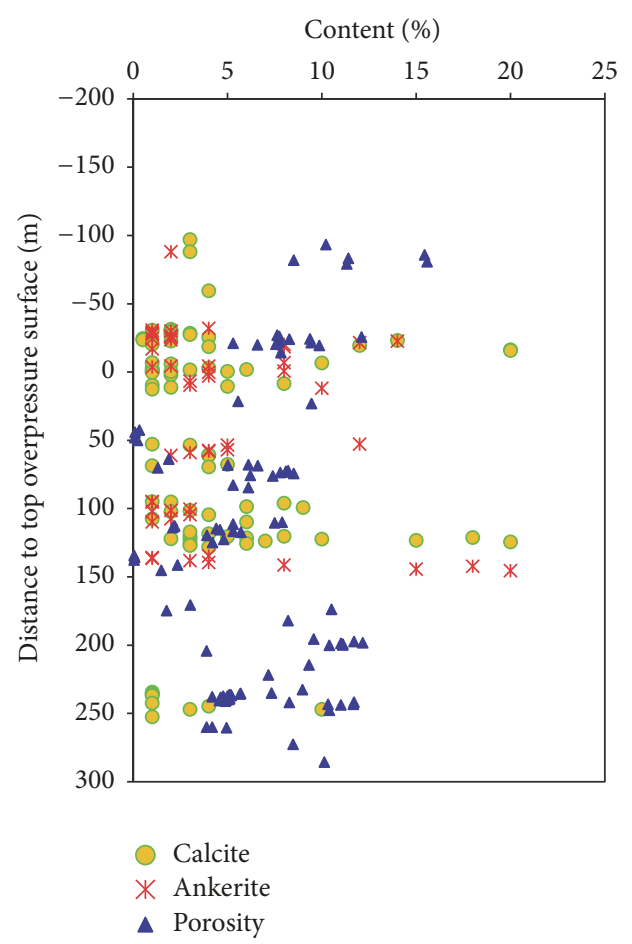

FIGURE 8: Relations between carbonate content, porosity, and distance to top overpressure surface of Block 3 . 


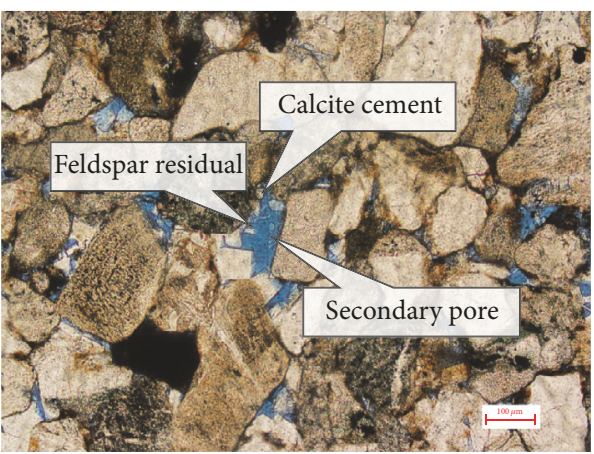

(a)

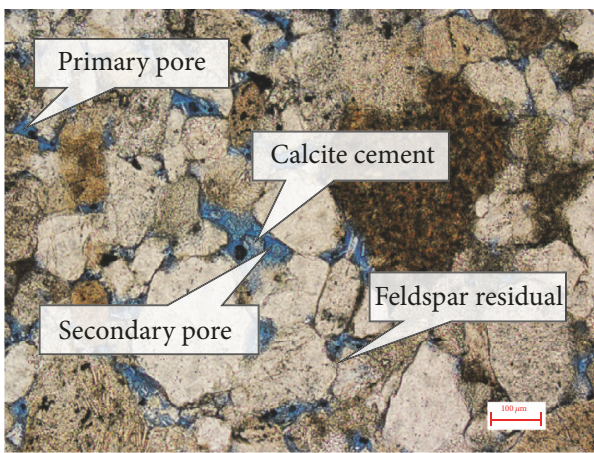

(c)

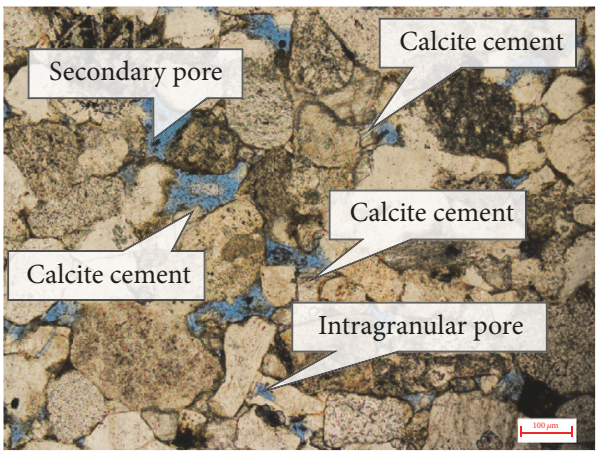

(e)

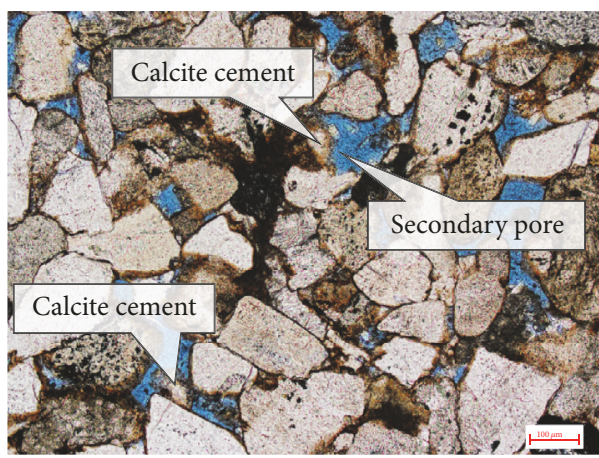

(g)

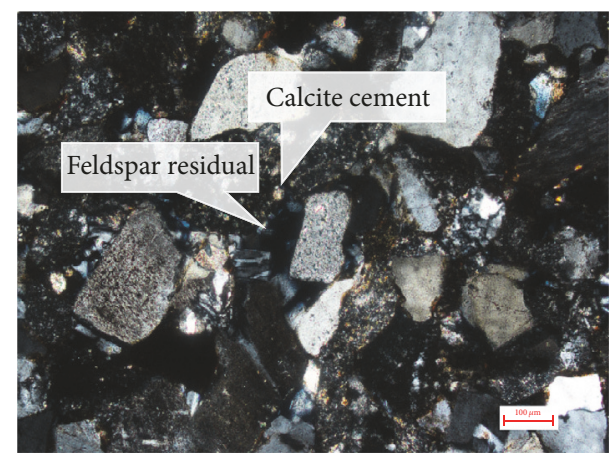

(b)

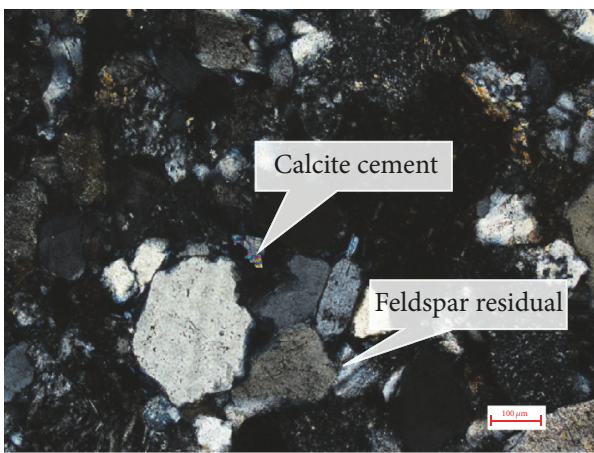

(d)

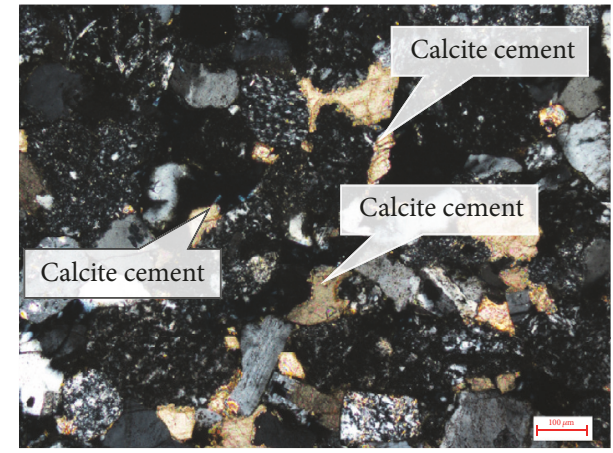

(f)

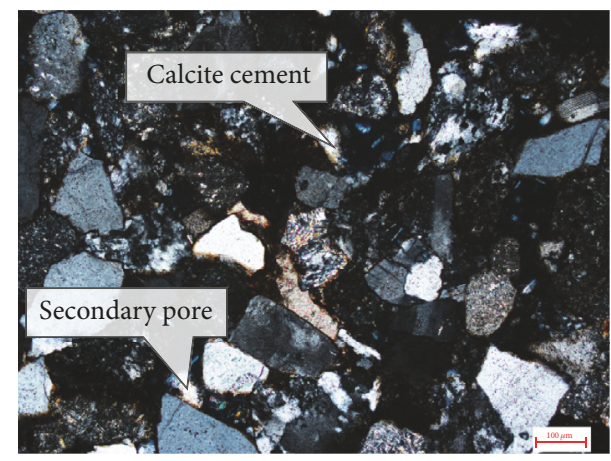

(h)

FIGURE 9: Photomicrographs of petrographic features of the Xishanyao Formation sandstones. Full view of pores and intergranular secondary pores develops from a blue-epoxy-impregnated thin sections of conventional core samples. The remnant of calcite and feldspar can be found after dissolution. (a), (b) Y2 well at $5961.5 \mathrm{~m}$ with magnification of 40; (c), (d) Y6 well at $5978 \mathrm{~m}$ with magnification of 40; (e), (f) Y1 well at $5876.3 \mathrm{~m}$ with magnification of 40; (g), (h) Y7 well at $6102.95 \mathrm{~m}$ with magnification of 40. 


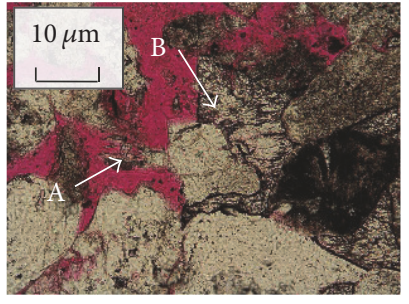

(a)

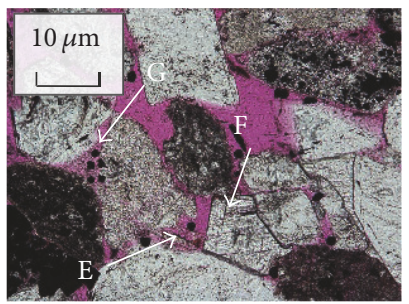

(c)

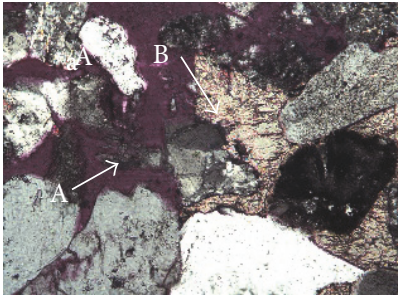

$\left(\mathrm{a}^{\prime}\right)$

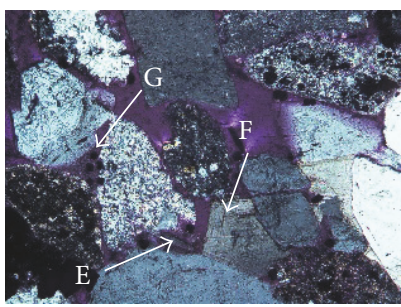

$\left(c^{\prime}\right)$

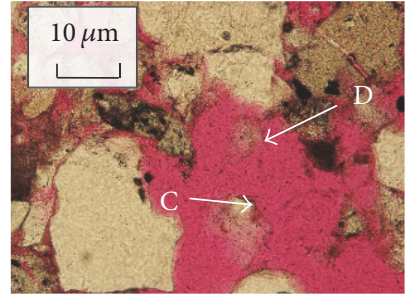

(b)

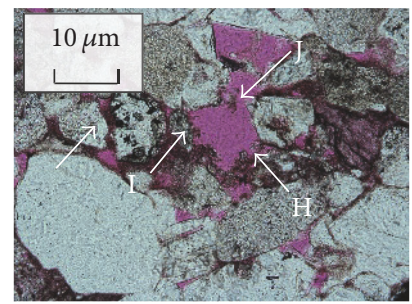

(d)

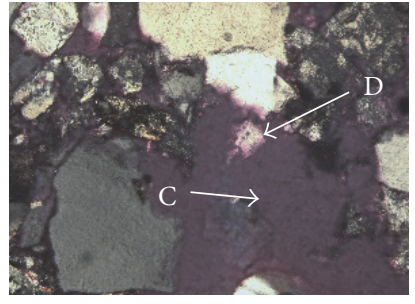

$\left(b^{\prime}\right)$

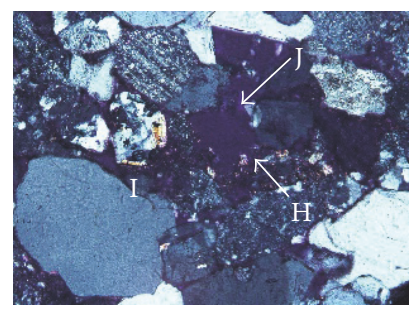

(d')

FIGURE 10: Photomicrographs of pore types by electron microprobe analysis of sandstones in central Junggar Basin. (a) and (a') Intergranular secondary pore develops, and measuring point A shows that the remnant is K-feldspar and the measuring point B is calcite. The photomicrograph is a red-epoxy-impregnated thin sections of conventional core samples with magnification of 10 (Sha 1 well at $3656.6 \mathrm{~m}$ with Jurassic) and photo (a) by plane-polarized light and photo $\left(\mathrm{a}^{\prime}\right)$ by cross polarization; (b) and $\left(\mathrm{b}^{\prime}\right)$ intergranular secondary pore develops, and measuring point $\mathrm{C}$ shows that the remnant is albite and measuring point $\mathrm{D}$ is $\mathrm{K}$-feldspar. The photomicrograph is a red-epoxy-impregnated thin sections of conventional core samples with magnification of 10 (Zhuang 1 well at $4375.23 \mathrm{~m}$ with Jurassic), and photo (b) by planepolarized light and photo $\left(b^{\prime}\right)$ by cross polarization; $(c)$ and $\left(c^{\prime}\right)$ intergranular secondary pore develops, measuring point E shows that the remnant is albite. Measuring point $\mathrm{F}$ is calcite and measuring point $\mathrm{G}$ is siderite, and the photomicrograph is a red-epoxy-impregnated thin sections of conventional core samples with magnification of 10 (Sha 2 well at $3439 \mathrm{~m}$ with Jurassic) and photo (c) by plane-polarized light and photo $\left(\mathrm{c}^{\prime}\right)$ by cross-polarized light; $(\mathrm{d})$ and $\left(\mathrm{d}^{\prime}\right)$ intergranular secondary pore develops, and measuring point $\mathrm{H}$ shows that the remnant is calcite, measuring point I is $\mathrm{K}$-feldspar, and measuring point $\mathrm{J}$ is albite. The photomicrograph is a red-epoxy-impregnated thin sections of conventional core samples with magnification of 10 (Y1 well at $5877 \mathrm{~m}$ with Jurassic) and photo (d) by plane-polarized light and photo (d') by cross-polarized light.

the porosity. In these two ways, the high porosity and high content of carbonate cements developed in the same burial depth [44].

Carbonate cements commonly occurred as irregularly distributed concretions even at the same depth, so it is challenging to predict porosity and permeability in the subsurface from spaced wells. Thin sections can provide a continuous image of heterogeneity produced by concretionary calcite cements. Our thin section images indicate a negative correlation between the carbonate cements and porosity development. Perhaps this phenomenon elaborates that intergranular pores, developing in deeply buried sandstones, result from early carbonate cements dissolving and migration. Therefore, early carbonate cements develop widely and secondary porosity is higher at later diagenetic phase.

The late generation of poikilotopic calcite is interpreted as a result of plagioclase and early calcite dissolution, which releases cations into pore water and may also be responsible for the precipitation of clay minerals and the silica cements [45]. From Figure 3, Ro were in $0.7-1.0 \%$. Thin section observations show that calcite formation is strongly associated with alteration of plagioclase. Among the common rock-forming minerals, plagioclase (especially calcium-rich plagioclase) is dissolved more rapidly than the other silicate phases [46], indicating that porosity generation may primarily result from plagioclase dissolution in deeply burial location. With the increasing of depth, temperature, and thermal maturity, calcite dissolution will be gradually weakened [5]. According to thin sections, primary porosity developed before the depth $3500 \mathrm{~m}$, secondary porosity mainly developed between 3500-6200 m, and cracks begin to develop from $6200 \mathrm{~m}$ [47, 48]. Therefore, during the deep-burial water-rock interaction processes, a lower secondary porosity zone resulting from plagioclase dissolution at depth greater than $6500 \mathrm{~m}$ would develop (Figure 11).

\section{Conclusions}

In Block 3 of the central Junggar Basin, carbonate cements are the predominant cements. Conventional core samples, epoxy-impregnated thin section analysis, and cathodoluminescence analysis indicate that the growth of carbonate cements has two stages and mostly formed at the late diagenetic stage, generating ferroan calcite and ankerite cements.

Data from the six wells demonstrate that carbonate cements of most of the samples are less than $20 \%$ and generally in the range of $1-10 \%$. The concentration of carbonate cements increases with increasing burial depth. Carbonate cements mainly concentrate in the depth range $+50 \mathrm{~m} \sim$ $-200 \mathrm{~m}$ to the top overpressure surface. 


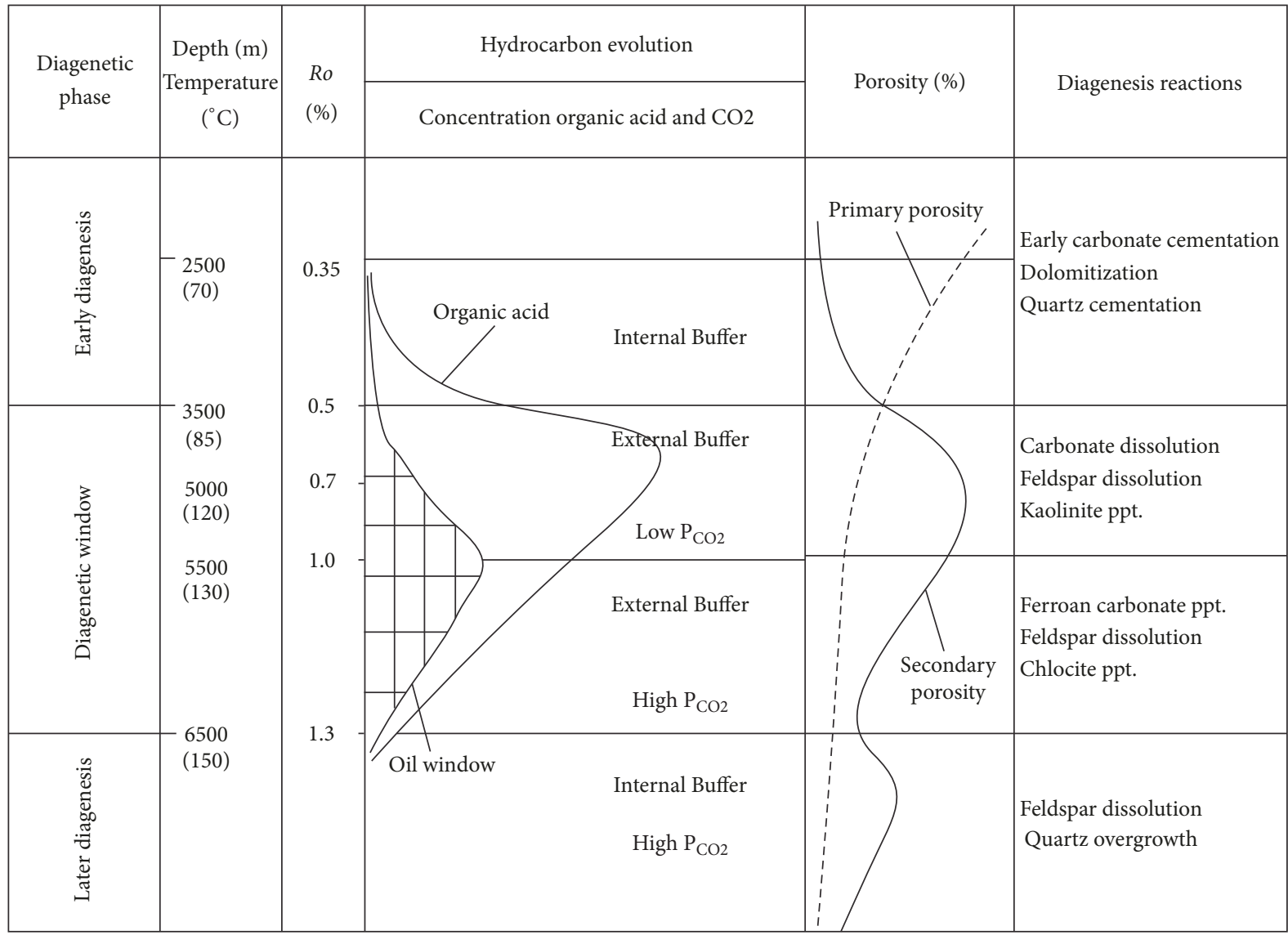

FIGURE 11: Diagenetic reactions, porosity, and hydrocarbon evolution of the different diagenetic phase in Block 3.

Stable isotopic data shows that $\delta^{13} \mathrm{C}_{\mathrm{PDB}}$ ranges from -19.07 to $-5.87 \%$ and $\delta^{18} \mathrm{O}_{\mathrm{PDB}}$ ranges from -21.08 to $-13.96 \%$. This suggests that the carbonate cements in these sandstones were significantly influenced by organic matter during burial history.

Electron microprobe analysis documents that the secondary intergranular pores primarily resulted from dissolving intergranular carbonate cements and feldspar. The chemical compaction and large-scale cementation restricted the dissolving capability of organic acid on late carbonate cements.

Textural data suggest that the late poikilotopic calcite, near the top overpressure surface, is rich in $\mathrm{Fe}$ and high porosity is developed in the same depth interval. This can be interpreted as a result of the dissolution of plagioclase. Therefore, another secondary porosity zone is supposed to develop, resulting from plagioclase dissolution at depth greater than $6500 \mathrm{~m}$. However, because of the chemical compaction and quartz overgrowth, the porosity scale will be smaller than the porosity developed at the depth of $5500 \mathrm{~m}$.

\section{Conflicts of Interest}

The authors declare that there are no conflicts of interest regarding the publication of this paper.

\section{References}

[1] R. Hesse and L. A. Abid, "Carbonate cementation-the key to reservoir properties of four sandstone levels (cretaceous) in the hibernia oil field, jeanne d'arc basin, newfoundland, Canada," in Carbonate Cementation in Sandstones: Distribution Patterns and Geochemical Evolution, International Association of Sedimentologists Special Publication, vol. 26, pp. 363-393, Wiley Online Library, Oxford, UK, 1998.

[2] S. Liu, S. Huang, Z. Shen, Z. Lü, and R. Song, "Diagenetic fluid evolution and water-rock interaction model of carbonate cements in sandstone: An example from the reservoir sandstone of the Fourth Member of the Xujiahe Formation of the Xiaoquan-Fenggu area, Sichuan Province, China," Science China Earth Sciences, vol. 57, no. 5, pp. 1077-1092, 2014.

[3] D. Xiong, K. Azmy, and N. J. F. Blamey, "Diagenesis and origin of calcite cement in the Flemish Pass Basin sandstone reservoir (Upper Jurassic): Implications for porosity development," Marine and Petroleum Geology, vol. 70, pp. 93-118, 2016.

[4] C. D. Curtis, "Possible links between sandstone diagenesis and depth-related geochemical reactions occurring in enclosing mudstones," Journal of the Geological Society, vol. 135, no. 1, pp. 107-117, 1978.

[5] R. C. Surdam, L. J. Crossey, E. S. Hagen, and H. P. Heasler, "Organic-inorganic interactions and sandstone diagenesis," AAPG Bulletin, vol. 73, no. 1, pp. 1-23, 1989.

[6] S. D. Weedman, S. L. Brantley, R. Shiraki, and S. R. Poulson, "Diagenesis, Compaction, and Fluid Chemistry Modeling of a 
Sandstone Near a Pressure Seal: Lower Tuscaloosa Formation, Gulf Coast," AAPG Bulletin, vol. 80, no. 7, pp. 1045-1064, 1996.

[7] K. Bjorlykke, "Geofluids: Origin, migration and evolution of fluids in sedimentary basins," in Fluid-flow processes and diagenesis in sedimentary basins, L. Parnell, Ed., vol. 78 of Geological Society Special Publication, pp. 127-140, 1994.

[8] F. L. Lynch, "Mineral/water interaction, fluid flow, and Frio sandstone diagenesis: evidence from the rocks," AAPG Bulletin, vol. 80, no. 4, pp. 486-504, 1996.

[9] Z. Zhihuan, H. Wenxuan, Z. Jianhui, Y. Bingsong, and L. Xiancai, "Study of fluid-rock interaction in Eogene Formation in Dongying Depression, Bohai Gulf Basin," Acta Sedimentologica Sinica, vol. 18, no. 4, pp. 560-566, 2000.

[10] S. P. Dutton, C. D. White, B. J. Willis, and D. Novakovic, "Calcite cement distribution and its effect on fluid flow in a deltaic sandstone, Frontier Formation, Wyoming," AAPG Bulletin, vol. 86, no. 12, pp. 2007-2021, 2002.

[11] K. Al-Ramadan, S. Morad, J. N. Proust, and I. Al-Aasm, "Distribution of diagenetic alterations in siliciclastic shoreface deposits within a sequence stratigraphic framework: evidence from the Upper Jurassic, Boulonnais, NW France," Journal of Sedimentary Research, vol. 75, no. 5, pp. 943-959, 2005.

[12] R. Jonk, A. Hurst, D. Duranti, J. Parnell, A. Mazzini, and A. E. Fallick, "Origin and timing of sand injection, petroleum migration, and diagenesis in Tertiary reservoirs, south Viking Graben, North Sea," AAPG Bulletin, vol. 89, no. 3, pp. 329-357, 2005.

[13] F. Hao, H. Zou, Y. Fang, and J. Hu, "Kinetics of organic matter maturation and hydrocarbon generation in overpressure environment," Shiyou Xuebao/Acta Petrolei Sinica, vol. 27, no. 5, pp. 9-18, 2006.

[14] M. I. Odigi and L. C. Amajor, "Geochemistry of carbonate cements in Cretaceous sandstones, southeast Benue Trough, Nigeria: Implications for geochemical evolution of formation waters," Journal of African Earth Sciences, vol. 57, no. 3, pp. 213226, 2010.

[15] B. T. T. Nguyen, S. J. Jones, N. R. Goulty et al., "The role of fluid pressure and diagenetic cements for porosity preservation in Triassic fluvial reservoirs of the Central Graben, North Sea," AAPG Bulletin, vol. 97, no. 8, pp. 1273-1302, 2013.

[16] F. García-García, R. Marfil, G. A. De Gea et al., "Reworked marine sandstone concretions: A record of high-frequency shallow burial to exhumation cycles," Facies, vol. 59, no. 4, pp. 843-861, 2013.

[17] S. L. Nyman, R. M. Gani, J. P. Bhattacharya, and K. Lee, “Origin and distribution of calcite concretions in Cretaceous Wall Creek Member, Wyoming: Reservoir-quality implication for shallowmarine deltaic strata," Cretaceous Research, vol. 48, pp. 139-152, 2014.

[18] Z. Ming, Z. Weihai, and Q. Jiangxiu, "The character and origin of overpressure and its explorational significance in Junggar Basin," Petroleum Exploration and Development, vol. 27, no. 2, pp. 31-35, 2000.

[19] W.-H. Zhang, M. Zha, and J.-X. Qu, "Overpressure and mechanisms of hydrocarbon accumulation in tertiary of southern Junggar Basin," Journal of the University of Petroleum, vol. 28, no. 1, pp. 10-12, 2004.

[20] W. Kongyou, Z. Ming, W. Xulong, Q. Jiangxiu, and X. Chen, "Further researches on the tectonic evolution and dynamic setting of the Junggar Basin," Acta Geoscientica Sinica, vol. 26, no. 3, pp. 217-222, 2005.
[21] S. He, Z.-L. He, Z. Yang, H.-Z. Wu, F.-R. Wang, and W.-Z. Shi, "Characteristics, well-log responses and mechanisms of overpressures within the Jurassic formation in the central part of Junggar basin," Diqiu Kexue - Zhongguo Dizhi Daxue Xuebao/Earth Science - Journal of China University of Geosciences, vol. 34, no. 3, pp. 457-470, 2009.

[22] K. Xi, Y. Cao, Y. Wang et al., "Diagenesis and porositypermeability evolution of low permeability reservoirs: A case study of Jurassic Sangonghe Formation in Block 1, central Junggar Basin, NW China," Petroleum Exploration and Development, vol. 42, no. 4, pp. 475-485, 2015

[23] Z. Yang, S. He, Q. Li, S. Lin, and S. Pan, "Geochemistry characteristics and significance of two petroleum systems near top overpressured surface in central Junggar Basin, NW China," Marine and Petroleum Geology, vol. 75, pp. 341-355, 2016.

[24] J. Kuang, Y. Genshun, and Z. Guohua, "The Origin of Favorable Sandstone Reservoirs of Sangonghe Formation, Lower Jurassic in Central Junggar Basin," Petroleum Exploration and Development, vol. 28, no. 6, pp. 34-37, 2001.

[25] S. Jianfeng, Z. Xingping, S. Chunsong, Z. Huiliang, and G. Mozhen, "Basic Types of High-quality Clastic Reservoirs Deepburied in Superimposed Basins in China," China Petroleum Exploration, vol. 11, no. 1, pp. 11-16, 2006.

[26] X. Guosheng, L. Jianlin, Z. Ping, L. Feng, and L. Yisha, "Diagenesis and pore formation mechanism of jurassic and cretaceous reservoirs in block 3 in the middle of Junggar Basin," Journal of Oil and Gas Technology, vol. 29, no. 3, pp. 1-7, 2007.

[27] S. Epstein, R. Buchsbaum, H. A. Lowenstam, and H. C. Urey, "Revised carbonate-water isotopic temperature scale," Bulletin of the Geological Society of America, vol. 64, no. 11, pp. 1315-1326, 1953.

[28] H. Li, M. Jiang, Y. Wang, L. Zhang, and G. Yu, "Image of crust and upper mantle structure along the array from fuyun to kuerle by P-to-S converted waves," Acta Geologica Sinica, vol. 80, no. 1, pp. 135-141, 2006.

[29] K. Yuzhu, "Targets of Paleozoic in Junggar Basin," Petroleum Prospect and Exploration, vol. 31, no. 5, pp. 449-453, 2010.

[30] K. Zhihong, "Evolution of paleozoic sedimentation of the junggar basin," Journal of Geomechanics, vol. 17, no. 2, pp. 158174, 2011.

[31] S. Jiye, Q. Mingkuan, C. Yuqi, and H. Zhongbo, "Basement charateristics of junggar basin and its effect on sandstone-type uranium metallogenesis," Geological Review, vol. 61, no. 1, pp. 128-138, 2015.

[32] X. Wu, D. He, D. Yang, X. Qi, and Y. Tang, "Structural character and hydrocarbon accumulation in the Luliang uplift, Junggar Basin," Scientia Geologica Sinica, vol. 47, no. 1, pp. 73-91, 2012.

[33] Z. He, S. Gao, and M. Zheng, "Regional tectonic framework and evolution of superimposed basins in northwestern China," Earth Science Frontiers, vol. 22, no. 3, pp. 227-240, 2015.

[34] P. Changchun, Z. Zhongyi, F. Shanfa, X. Qilai, W. Xulong, and W. Yutao, "Thermal history of Junggar Basin," Geochimica, vol. 26, no. 6, pp. 1-7, 1997.

[35] W. Xulong, Y. Haibo., and Q. Yongxin, "Basin modeling technique and JunMod basin modeling software," Computer Application of Petroleum, vol. 2, pp. 18-24, 2001.

[36] Q. Nansheng, Z. Ming, and W. Xulong, "Simulation of geothermal evolution history in junggar basin," Xinjiang Petroleum Geology, vol. 21, no. 1, pp. 38-41, 2000.

[37] N. Qiu, H. Yang, and X. Wang, "Tectono-thermal evolution in the Junggar Basin," Chinese Journal of Geology, vol. 37, no. 4, pp. 423-429, 2002. 
[38] W. Yin, B.-W. Bie, and G.-L. Liu, "The characteristics of fluid inclusions and its application to identifying oil accumulating stages in central depression, Junggar Basin," Bulletin of Mineralogy, Petrology and Geochemistry, vol. 28, no. 1, pp. 53-60, 2009.

[39] H. Irwin, C. Curtis, and M. Coleman, "Isotopic evidence for source of diagenetic carbonates formed during burial of organic-rich sediments," Nature, vol. 269, no. 5625, pp. 209-213, 1977.

[40] R. C. Surdam, S. W. Boese, and L. J. Crossey, "The chemistry of secondary porosity," in Clastic Diagenesis, D. A. McDonald and R. C. Surdam, Eds., pp. 127-149, AAPG Memoir, 1984.

[41] S. Morad, "Carbonate cementation in sandstones; distribution patterns and geochemical evolution," in Carbonate Cementation in Sandstones, S. Morad, Ed., vol. 26 of Special Publication, pp. 126, International Association of Sedimentologists, Oxford, UK, 1998.

[42] L.-Q. Zhang, "Distribution and origin of ferrocalcite cements in Paleogene overpressure sandstones on the south margin of Junggar Basin, Xinjiang, China," Journal of Chengdu University of Technology. Science and Technonogy, vol. 38, no. 6, pp. 625632, 2011.

[43] Y.-Z. Wang, Y.-C. Cao, S.-M. Zhang, F.-L. Li, and F.-C. Meng, "Genetic mechanisms of secondary pore development zones of Es $4 \mathrm{x}$ in the north zone of the Minfeng Sag in the Dongying Depression, East China," Petroleum Science, vol. 13, no. 1, pp. 1$17,2016$.

[44] H. Sijing, H. Peipei, W. Qingdong, L. Haonian, W. Meng, and Z. Mingliang, "The significance of cementation in porosity preservation in deep-buried sandstones," Lithologic Reservoirs, vol. 19, no. 3, pp. 7-13, 2007.

[45] R. M. Siebert, G. K. Moncure, and R. W. Lahann, "A theory of framework grain dissolution in sandstones," in Clastic Diagenesis, D. A. McDonald and R. C. Surdam, Eds., vol. 37, AAPG Memoir, Tulsa, OK, 1984.

[46] R. H. McNutt, S. K. Frape, P. Fritz, M. G. Jones, and I. M. MacDonald, "The $87 \mathrm{Sr} 86 \mathrm{Sr}$ values of Canadian Shield brines and fracture minerals with applications to groundwater mixing, fracture history, and geochronology," Geochimica et Cosmochimica Acta, vol. 54, no. 1, pp. 205-215, 1990.

[47] Z. Yang, S. He, F. Wang, Z. He, H. Wu, and X. Meng, "Character istics and genetic mechan ism of carbonate cement in sandstone reservoirs of Yongjin area in central Junggar Basin," Acta Petrologica et Mineralogica, vol. 28, no. 2, pp. 169-178, 2009.

[48] W. Furong and H. Sheng, "The reservoir characteristic ofdeeplyburied sandstone in the Center of Junggar Basin," Petroleum Geology and Experiment, vol. 32, no. 6, pp. 547-552, 2010. 

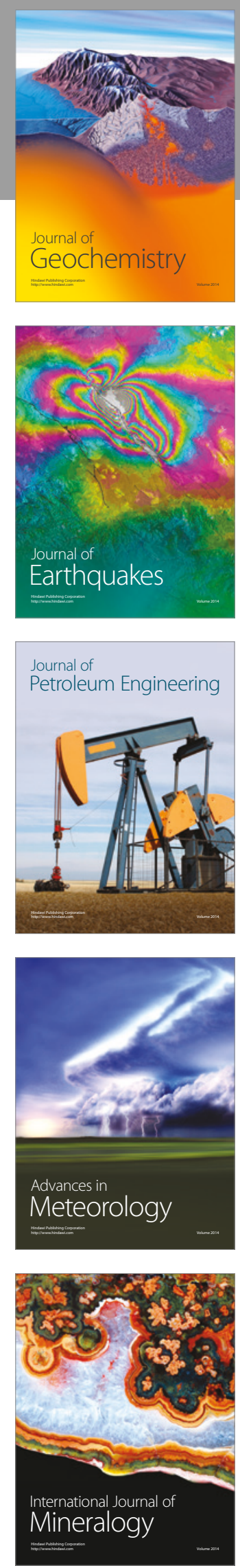
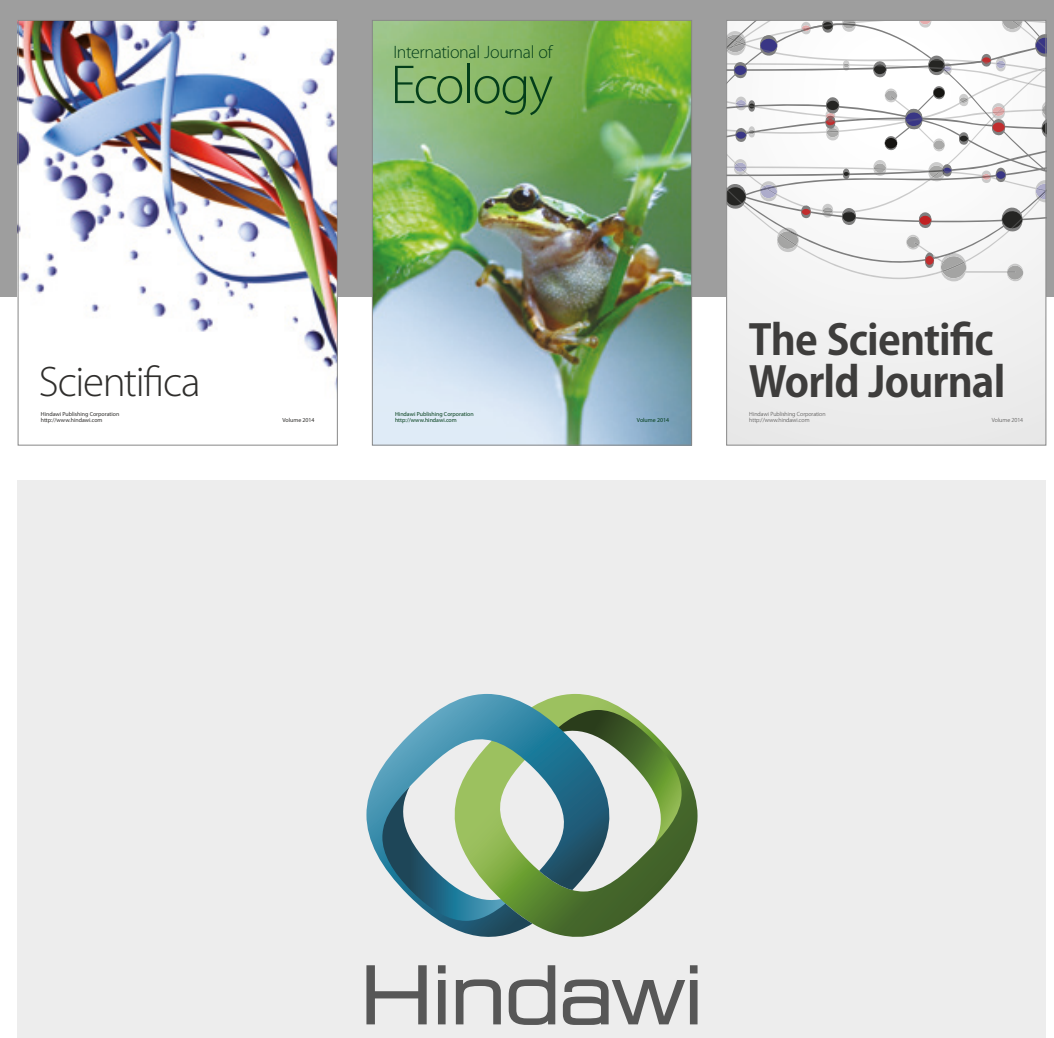

Submit your manuscripts at

https://www.hindawi.com
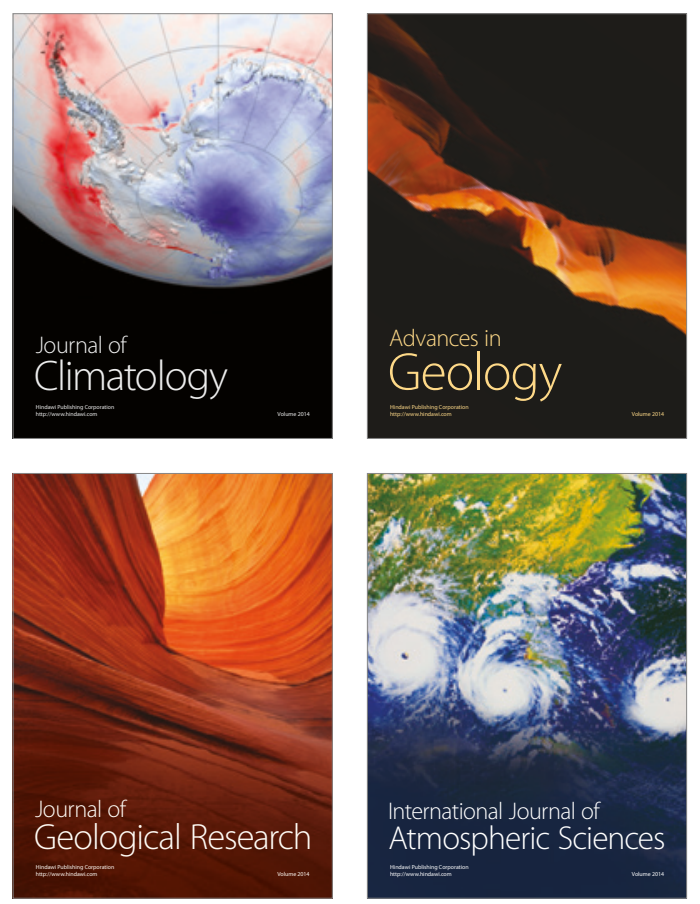

The Scientific

World Journal
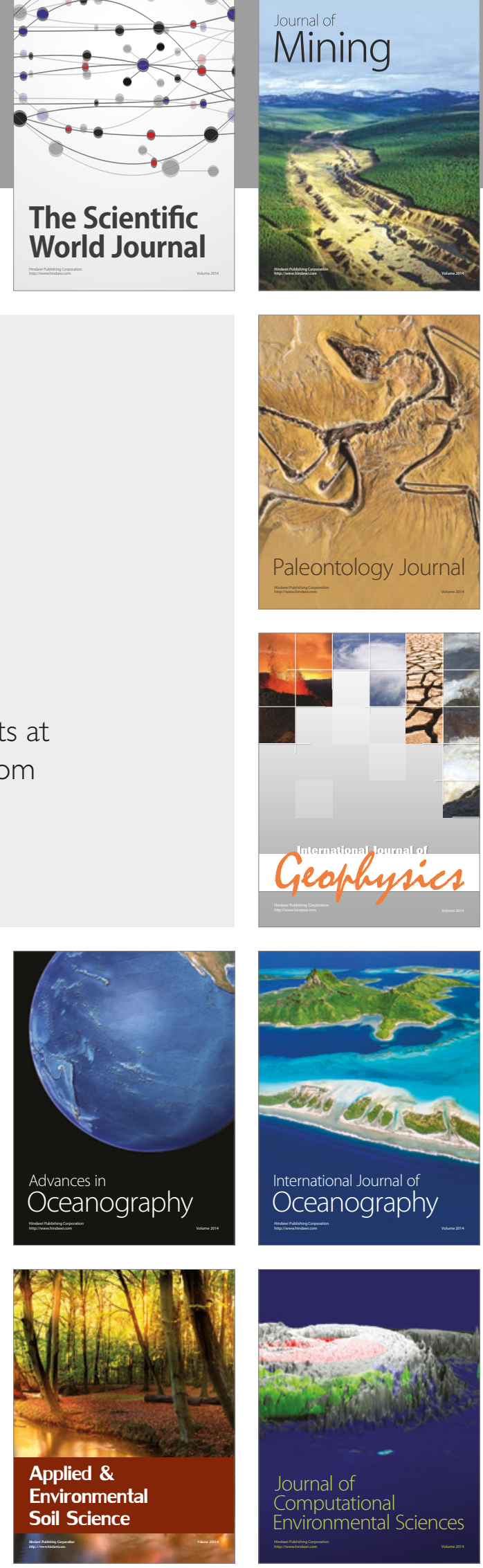